\title{
OPTIMALISASI KECERDASAN BAHASA ANAK USIA DINI MELALUI METODE BERMAIN PERAN
}

\author{
Indah Fajrotuz Zahro \\ STAI Attanwir Bojonegoro \\ Email: indahfajrotuzzahro@gmail.com
}

\begin{abstract}
Language is one of the important aspects for early childhood development. Language functions as a means of communication as well as being an important means for the lives of children. It is dangerous to be a means for children to be able to interact with each other, share their experiences, and be able to improve intellectually, namely in order to develop their language knowledge and skills. For early childhood it is a period of development that must be fostered and developed so that they can make full use of their language skills. If the guidance, direction, and handling are not appropriate or even not obtained by the child causes language development that is not in accordance with what is expected by parents at home or by educators at school. The methods that can be done to stimulate and optimize children's language intelligence, including the method of question and answer, storytelling, tourist visits and play play (dramatic play). The role playing method consists of playing the role of macro and micro by going through the stages of playing an artificial role, playing with the object, pretending to be related to actions and circumstances, perseverance and oral communication. Based on data analysis and discussion, information can be obtained that the method of playing drama (play dramatically) / role playing is carried out in several stages, namely identifying figures, determining story settings, interpreting stories and values contained, reflection and observation. The application of this technique is expected to provide optimization of early childhood language intelligence.
\end{abstract}

Keywords: Language Intelligence, Role Playing

\section{Pendahuluan}

Awal masa kanak-kanak umumnya merupakan saat berkembang pesatnya penguasaan tugas pokok dalam belajar berbicara, yaitu menambah kosakata, menguasai pengucapan katakata dan menggabungkan kata-kata menjadi kalimat (Hurlock, 2004: 113). Kalimat yang tersusun tersebut akan menjadi referensi bagi anak untuk berbicara kepada orang lain, baik kepada orang tua, saudara, teman dan orang di sekitarnya.

Selama masa awal kanak-kanak, anak-anak memiliki keinginan yang kuat untuk belajar berbicara. Hal ini disebabkan karena dua hal. Pertama, belajar berbicara merupakan sarana pokok dalam sosialisasi. Anak-anak yang lebih mudah berkomunikasi dengan teman 
sebaya akan lebih mudah mengadakan kontak sosial dan lebih mudah diterima sebagai anggota kelompok daripada anak yang kemampuan berkomunikasinya terbatas. Anak-anak yang mengikuti kegiatan prasekolah akan mengalami rintangan baik dalam hal sosial maupun pendidikan kecuali bila ia pandai bicara seperti teman-teman sekelasnya. Kedua, belajar berbicara merupakan sarana untuk memperoleh kemandirian. Anak-anak yang tidak dapat mengemukakan keinginan dan kebutuhannya, atau yang tidak dapat berusaha agar dimengerti orang lain cenderung diperlakukan sebagai bayi dan tidak berhasil memperoleh kemandirian yang diinginkan (Hurlock, 2004: 112). Awal masa kanak-kanak terkenal sebagai masa tukang ngobrol, karena sekali anak-anak dapat berbicara dengan mudah, ia tak putus-putusnya bicara. Sebaliknya, ada anak-anak lain yang relatif diam, yang tergolong pendiam (Hurlock, 2004: 114).

Sosialisasi dan kemandirian merupakan tugas perkembangan bagi anak usia dini. Berdasarkan observasi di taman kanak-kanak, banyak ditemui anak yang pendiam cenderung bermain sendiri daripada bersosialisasi dengan teman-temannya. Ataupun ketika bermain bersama, komunikasi hanya bersifat satu arah. Selain itu, anak yang percaya diri dalam menyampaikan keinginan dan kebutuhannya lebih komunikatif dan mandiri untuk meraih keinginannya, sebaliknya anak yang cenderung kurang berbicara ada kecenderungan untuk dimengerti oleh lain dan cenderung kurang mandiri.

Bahasa merupakan salah satu aspek penting dalam perkembangan pada anak usia dini. Bahasa berfungsi sebagai salah satu alat komunikasi dan merupakan sarana penting dalam kehidupan anak. Melalui bahasa, anak dapat saling berhubungan, saling berbagai pengalaman, dan dapat meningkatkan intelektual, yakni dalam rangka pengembangan pengetahuan dan keterampilan bahasanya. Bagi anak usia dini hal tersebut merupakan masa perkembangan yang harus dibina dan dikembangkan agar mereka dapat memanfaatkan kemampuan bahasanya secara maksimal. Jika bimbingan, arahan, dan penanganan tidak tepat atau bahkan tidak diperoleh oleh anak sangat mungkin terjadi perkembangan bahasa yang tidak sesuai dengan yang diharapkan oleh orang tua di rumah maupun oleh pendidik di sekolah (Anita, 2015: 162).

Kemampuan berbicara anak dapat diketahui dari isi pembicaraan dan jumlah bicara. Pada mulanya, pembicaraan anak-anak bersifat egosentris dalam arti ia terutama berbicara tentang dirinya sendiri, berkisar pada minat, keluarga dan miliknya. Menjelang akhir awal kanak-kanak mulailah pembicaraan yang bersifat sosial dan anak berbicara tentang orang lain 
di samping dirinya sendiri. Namun banyak dari pembicaraan sosial awal ini sebenarnya tidak bersifat sosial karena isinya lebih banyak mengarah pada kritik kepada orang lain dalam bentuk pengaduan atau keluhan. Kebanyakan anak-anak juga memberi komentar buruk, komentar yang merendahkan orang lain mengenai perilaku dan miliknya. Anak-anak juga suka memaki-maki terutama pada saat marah. Pada usia ini anak-anak jarang membual, terutama tentang miliknya (Hurlock, 2004: 114).

Mengetahui pentingnya peranan bahasa bagi anak maka dilakukan beberapa upaya untuk meningkatkan kemampuan berbahasa melalui berbagai metode. Metode adalah cara yang digunakan bagi pendidik dan orangtua untuk menstimulasi perkembangan bahasa anak agar berkembang sesuai dengan tahapannya.

Penggunaan metode pembelajaran pada pembelajaran sangat penting, karena tidak semua metode pembelajaran tepat untuk semua penyampaian, waktu, kondisi dan bidang pengembangan. Salah satu penentu dalam kegiatan belajar mengajar adalah metode. Dalam kegiatan berkomunikasi, bahasa merupakan alat yang penting bagi setiap orang. Melalui berbahasa seseorang atau anak akan dapat mengembangkan kemampuan bergaul (social skill) dengan orang lain. Permainan sosiodrama atau bermain peran merupakan permainan yang sangat baik untuk meningkatkan kecerdasan bahasa anak (Musfiroh dalam Choiriyah S, dkk).

Berdasarkan uraian diatas diketahui bahwa bahasa memiliki peranan penting bagi perkembangan kehidupan anak di masa mendatangnya dan salah satu upaya yang dapat dilakukan untuk mengoptimalkan kecerdasan bahasa anak adalah dengan menggunakan metode bermain peran.

\section{Kecerdasan Berbahasa}

Gardner (dalam Chatib, 2011: 132) menyatakan bahwa intelligence is the ability to find and solve problems and create products of value in one's own culture. Chatib (2011: 132) menambahkan bahwa kecerdasan seseorang dapat dilihat dari kebiasaan seseorang terhadap dua hal. Pertama, kebiasaan seseorang menyelesaikan masalahnya sendiri (problem solving). Kedua, kebiasaan seseorang menciptakan produk-produk baru yang punya nilai budaya (creativity). 
Kridalaksana (dalam Indriati, 2011: 22) mendefinisikan bahasa sebagai sebagai tanda bunyi yang disepakati untuk digunakan oleh anggota kelompok masyarakat tertentu dalam bekerja sama, berkomunikasi, dan mengekspresikan diri.

Gunawan (2012: 232) menjelaskan bahwa kecerdasan linguistik (berbahasa) adalah kemampuan menggunakan kata-kata secara efektif, baik secara lisan maupun tulisan. Kecerdasan ini mencakup kemampuan untuk menangani struktur bahasa (sintaksis), suara (fonologi) dan arti (semantik). Kecerdasan lisnguistik bersifat universal. Daerah Broca di otak kita bertanggungjawab terhadap kemampuan berkomunikasi, menghasilkan kalimat dengan struktur tata bahasa yang benar. Sedangkan daerah yang menangani pengertian terhadap informasi verbal yang kita dengar adalah daerah Wernick, pada lobus temporal.

Musfiroh (2005) menyatakan bahwa kecerdasan bahasa dapat dilihat sejak kanakkanak melalui ujaran (kata-kata) untuk tujuan komunikasi dan melalui kegiatan mendengarkan komunikasi dengan orang dan anak lain di sekitarnya. Kecerdasan bahasa mengandung domain:

1. Produksi, yakni kegiatan berbicara, berekspresi dan menjalin komunikasi dengan orang lain. Anak yang cerdas bahasa mampu berbicara dengan kata-kata yang jelas, bervariasi (banyak kata), dan mudah dimengerti. Anak yang cerdas bahasa ini cenderung berani menggunakan kata-kata baru, dan mencobanya dalam komunikasi sehari-hari meskipun mungkin keliru. Tetapi begitu mendapat koreksi, mereka cepat melakukan perbaikan,

2. Komprehensi, yakni kegiatan mendengarkan, menikmati cerita/ pembicaraan, dan memahami lelucon-lelucon dalam bentuk kata-kata. Anak yang cerdas bahasa, cepat mengerti perintah, pertanyaan-pertanyaan, pernyataan dan guyonan. Mereka suka mendengarkan orang berbicara dan menyerap informasinya, menikmati siaran radio atau siaran yang penuh dengan obrolan,

3. Bersenandika, yakni kegiatan berbicara dengan diri sendiri, mengolah informasi dan mendengarkan sendiri apa yang dikatakannya, menghibur diri dengan suara-suara yang dibuat sendiri, "berlaga" bicara sendiri. Anak yang cerdas bahasa peduli terhadap apa yang ingin dikatakan, menikmati apa yang diceritakannya.

Musfiroh (2005) juga menyatakan bahwa kecerdasan bahasa bukan hanya berkaitan dengan simbol audial (bunyi bahasa), tetapi juga warna suara, simbol visual (tulisan) dan kekuatan dari simbol-simbol itu. Anak-anak yang cerdas dalam bahasa: 
1. Cepat menandai ciri suara mitra bicara dalam berkomunikasi. Mereka memahami maksud dengan menyimak nada, irama dan warna bicara seseorang. Ketika kecerdasan bahasa berintegrasi dengan kecerdasan interpersonal, anak-anak menjadi tajam dalam menyimak sifat-sifat orang lain melalui nada dan irama berbicara,

2. Peka dan suka pada tulisan. Begitu melihat tulisan, anak-anak "memotret" dan merekam maknanya. Mereka tertarik melihat tulisan, merk, nama toko, atau apapun yang terpampang di jalan, papan reklame, dan judul buku. Mereka akan bertanya lalu mengingatnya. Apabila bentuk tulisan diubah, anak-anak akan bertanya kembali. Apabila ada huruf yang dihilangkan, mereka dengan cepat akan merasakan,

3. Suka meniru tulisan. Kegiatan mencorat-coret (pura-pura) menulis, merupakan indicator kecerdasan bahasa dalam hal minat. Anak-anak yang cerdas bahasa menunjukkan antusiasme dalam hal berekspresi tulis. Artinya, mereka suka berkomunikasi dengan "tulisan" atau pesan harian. Dalam tingkatan yang lebih tinggi, anak-anak akan senang membuat cerita, mengarang, atau membuat karya kreatif seperti "puisi", "komik" atau "cerita pendek",

4. Tertarik pada bahasa selain bahasanya. Anak-anak mungkin sekedar menirukan dialog di televisi atau infotainment. Peniruannya pun mungkin tidak sempurna. Mereka bangga karena merasa dapat "berbahasa asing", atau "berbicara dengan bahasa televisi". Anakanak dengan kecerdasan bahasa yang tinggi, dapat menirukan "bahasa asing" dengan lebih akurat daripada anak yang tidak begitu tinggi dalam poin ini.

Anita (2015: 172) menyebutkan bahwa pemerolehan bahasa anak usia dini akan berkembang dengan optimal dipengaruhi oleh beberapa faktor berikut, yakni:

1. Lingkungan yang kaya bahasa akan menstimulasi pemerolehan bahasa anak. Stimulasi tersebut akan optimal jika anak tidak merasa tertekan dari lingkungannya,

2. Orang-orang di sekitar anak menunjukkan sikap dan minat yang tulus pada anak. Anak usia dini emosinya masih kuat. Karena itu, orang dewasa perlu merespon anak dengan tulus,

3. Anak memiliki kemampuan menyampaikan pesan verbal diikuti pesan nonverbal. Dalam berkomunikasi, anak seringkali menggunakan bahasa nonverbal untuk memastikan maksud bahasa yang dia verbalkan. Misalnya, dia tidak hanya menyebutkan benda yang diinginkannya tetapi juga menunjuk benda tersebut,

4. Dalam bercakap-cakap dengan anak, orang dewasa perlu menunjukkan ekspresi yang sesuai dengan ucapannya. Perlu diikuti gerakan, mimik muka, dan intonasi yang sesuai. 
Misalnya: orang dewasa berkata "saya senang" maka perlu menunjukkan ekspresi muka senang, sehingga anak mengetahui seperti apa kata senang itu sesungguhnya,

5. Orang tua/ pendidik melibatkan anak dalam komunikasi. Orang dewasa perlu melibatkan anak untuk ikut membangun komunikasi. Kita menghargai ide-idenya dan memberikan respon yang baik terhadap bahasa anak.

\section{Metode Bermain Peran}

Bermain peran dikenal sebagai bermain pura-pura, dramatic, simbolik atau fantasi. Kegiatan bermain ini merupakan jenis bermain yang lazim dilakukan oleh anak usia 4-6 tahun. Kegiatan bermain peran dapat dilakukan seorang diri atau bersama dengan temantemannya, dengan menggunakan alat permainan maupun tanpa alat permainan ( $\mathrm{Sit}, \mathrm{M}, \mathrm{dkk}$, 2016: 57)

Metode bermain peran adalah metode yang melibatkan interaksi antara dua anak atau lebih tentang suatu topik atau situasi. Anak melakukan peran masing-masing sesuai dengan tokoh yang ia lakoni, mereka berinteraksi sesama mereka melakukan peran terbuka (Yamin, 2009: 75). Metode bermain peran adalah suatu cara penguasaan bahan pelajaran melalui pengembangan dan penghayatan anak didik. Pengembangan tersebut dilakukan dengan memerankannya sebagai tokoh hidup atau benda mati (Djamarah, 2005: 237)

Bermain peran adalah salah satu bentuk permainan pendidikan yang digunakan untuk menjelaskan perasaan, sikap, tingkah laku dan nilai, dengan tujuan menghayati beragam perasaan, sudut pandangan dan cara berpikir orang lain, sekaligus strategi untuk mengatasinya (Tedjasaputra, 2003: 34)

Menurut Moeslichatoen (dalam Jannati, 2016: 6), bermain peran adalah bermain menggunakan daya khayal yaitu dengan memakai bahasa atau berpura-pura bertingkah laku seperti benda tertentu, situasi tertentu, atau orang tertentu, dan binatang tertentu, yang dalam dunia nyata tidak dilakukan. Penggunaan metode bermain peran dapat membuat anak berekspresi, berkomunikasi secara lisan, menyampaikan perasaan, mengungkapkan ide/ gagasan, mengingat dan menghafalkan informasi, dan lain sebagainya.

Menurut Nuraini (2010: 82), tahapan bermain peran adalah sebagai berikut:

1. Guru mengumpulkan anak-anak untuk diberikan pengarahan dan aturan-aturan serta tata tertib dalam bermain 
2. Guru membicarakan alat-alat yang akan digunakan oleh anak-anak untuk bermain

3. Guru memberikan pengarahan sebelum bermain dan mengabsen anak-anak serta menghitung jumlah anak bersama-sama

4. Guru memberikan tugas kepada anak sebelum bermain menurut kelompoknya agar anak tidak saling berebut dalam bermain

5. Guru sudah menyiapkan anak-anak permainan yang akan digunakan sebelum anak-anak mulai bermain

6. Anak bermain sesuai perannya

7. Guru hanya mengawasi, mendampingi anak dalam bermain apabila dibutuhkan anak guru membantunya, guru tidak banyak bicara dan tidak banyak membantu anak

8. Setelah waktu bermain hampir habis, guru dapat menyiapkan berbagai macam buku cerita sementara guru merapikan permainan dengan dibantu oleh beberapa anak.

Sementara Smilansky (dalam Sit, M, dkk, 2016: 58) menyebutkan bahwa tahapan bermain peran adalah sebagai berikut:

1. Main peran tiruan. Cara memerankannya, anak meniru peran seseorang atau sesuatu yang lain. Misalnya, anak menirukan peran menjadi ibu atau yang lain,

2. Main pura-pura dengan objek. Cara memerankannya, anak menggunakan gerakan atau pernyataan lisan sebagai pengganti objek yang sebenarnya, misalnya anak menggunakan kotak sebagai mobil lalu anak membuat suara mobil sambil menjalankan kotak tersebut,

3. Pura-pura berkaitan dengan tindakan dan keadaan. Cara memerankannya, anak menggunakan bahasa sebagai pengganti untuk tindakan atau keadaan. Misalnya anak menirukan suara suatu benda atau peristiwa,

4. Ketekunan. Cara memerankannya, anak berlatih konsentrasi pada peran mereka, memulai dan mengakhiri sebuah naskah cerita. Misalnya anak bermain peran dalam sebuah cerita,

5. Komunikasi lisan. Cara memerankannya, anak berkomunikasi menurut peran-peran yang mereka mainkan, sehingga terjadi kerjasama dalam peran-peran yang mereka mainkan bersama-sama.

Menurut Erikson terdapat dua jenis permainan drama, yaitu

1. Peran besar, anak bermain dengan menjadi tokoh menggunakan alat dengan ukuran yang sesungguhnya. Anak memainkan peranperan seperti ayah, ibu, pedagang, pelayan, dokter; 
2. Peran kecil, anak memainkan peran dengan menggunakan alat yang berukuran kecil. Disini anak bertindak seperti sutradara atau dalang. Alat-alat yang digunakan misalnya rumah boneka, perabotan rumah, dan boneka-boneka pelengkap yang berukuran kecil sesuai dengan rumahnya yang juga kecil (dalam Massardi, S, dkk, 2012).

\section{Optimalisasi Kemampuan Berbahasa Anak Usia Dini melalui Metode Bermain Peran}

Bahasa memiliki peranan penting bagi perkembangan anak. Anak yang memiliki perkembangan bahasa yang sesuai dengan tahapannya akan memudahkan anak untuk bersosialisasi dan mandiri dalam menyelesaikan kegiatan practical life. Kemampuan berbahasa anak dapat distimulasi dan dioptimalkan dengan menggunakan berbagai metode. Antara lain dengan metode bercerita, tanya-jawab, kunjungan wisata dan bermain peran. Hal ini sesuai dengan disampaikan Anita (2015: 174) bahwa terdapat beberapa metode yang digunakan untuk mengembangkan kemampuan bahasa anak. Metode tersebut antara lain metode bercerita, bermain peran, permainan bahasa, bercakap-cakap, karya wisata, tanya jawab dan lain sebagainya.

Metode bermain peran atau dikenal sebagai bermain pura-pura, dramatic, simbolik atau fantasi sebagai upaya untuk meningkatkan kecerdasan bahasa anak telah banyak diteliti. Diantaranya, penelitian dari Jannati diperoleh hasil bahwa terdapat pengaruh metode bermain peran terhadap kecerdasan linguistik anak kelompok B di TK Dharma Wanita Kedungguwo, Sukomoro, Magetan (Jannati, 2016). Hal ini sesuai dengan penelitian yang menunjukkan bahwa penerapan bermain peran dapat meningkatkan kecerdasan berbahasa anak (Utami, $\mathrm{H}$. D, 2014). Penelitian dari Masganti (dalam Sit, M, dkk, 2016: 60) juga menunjukkan bahwa penerapan strategi pembelajaran bermain peran dapat meningkatkan kreativitas anak dalam berbahasa. Musfiroh (2005: 195) juga menyatakan bahwa permainan sosiodramatik merupakan permainan yang sangat baik untuk meningkatkan kecerdasan bahasa anak. Permainan ini merangsang kecerdasan anak dalam berekspresi dan berkompeten sekaligus.

Berdasarkan penelitian tindakan kelas diperoleh hasil bahwa kemampuan berkomunikasi lisan anak kelompok B TKIT Nur Hidayah mengalami peningkatan setelah dilaksanakan metode bermain peran. Adapun tahapan-tahapan dalam kegiatan bermain peran yaitu menghangatkan situasi kelas dengan menjelaskan tema yang dimainkan, memperkenalkan alat-alat yang akan digunakan dalam bermain, memilih partisipan atau 
pemilihan peran yang akan dimainkan, mengatur setting/ pentas dilakukan sebelum pembelajaran dimulai, memerankan peran yang telah dipilih, diskusi dan evaluasi tentang pengalaman bermain peran dan pemberian reward berupa pujian, tepuk tangan atau hadiah (Choiriyah, S, dkk)

Kecerdasan linguistik yang berkembang baik, bisa muncul dalam bentuk minat dan perhatian seseorang pada olah kata, hubungan kata-kata, sintaksis, keindahan dan substansi gaya bahasa, baik lisan maupun tulisan. Kecerdasan linguistik menjadi elemen paling jelas dalam suatu karya tulis yang baik. Manifestasi kecerdasan linguistik juga bisa dlihat pada kemahiran dalam permainan kata, bahkan termasuk mengisi teka-teki silang (Massardi S, dkk, 2012: 49).

Menurut Howard Gardner (dalam Massardi S, dkk, 2012: 50), kecerdasan linguistiklah yang memungkinkan pemrosesan simbol menjadi bahasa itu tidak tergantung semata-mata pada satu area otak saja. Dalam hal ini, Gardner berpendapat bahwa kecerdasan linguistik mencakup kualitas pemrosesan bahasa pada bagian otak kanan maupun kiri. Kecerdasan linguistik merupakan kombinasi keterlibatan beberapa sistem, yakni citarasa intonasi, kemampuan kognitif menyebutkan dan mengklasifikasi serta menguraikan struktur kalimat.

Kemampuan mempelajari bahasa ada dalam diri setiap anak. Tidak peduli anak itu lahir di mana dan dari suku bangsa atau negara apa. Apabila ia mendapat rangsangan auditori, anak akan mampu berbicara dengan bahasa yang digunakan di komunitasnya. Rangsangan auditori ini tentunya adalah bahasa yang digunakan orangtuanya (Gunawan, 2012: 232).

Untuk bisa berhasil dalam mempelajari suatu bahasa, mutlak dibutuhkan suatu lingkungan yang penuh dukungan, yang memperbolehkan terjadinya kesalahan dalam proses pembelajaran, lingkungan yang menyenangkan dan menantang. Lingkungan seperti ini sangat menentukan kecepatan dan keberhasilan penguasaan suatu bahasa, pada masa-masa puncak daya serap dan kemampuan anak mempelajari bahasa ibunya (Gunawan, 2012: 232).

Kegiatan bermain peran sangat membantu anak menuangkan gagasan-gagasan yang dimilikinya sekaligus mengembangkannya dalam berbagai bentuk kegiatan kreatif. Melalui kegiatan bermain peran anak akan mendapatkan pengalaman penting yang mengantarkan anak memperoleh pengetahuan dan keterampilan yang dibutuhkan bagi kehidupannya di kemudian hari. Pengalaman selama bermain peran akan mendukung semua aspek 
perkembangan anak, yaitu aspek agama dan moral, sosial-emosional, fisik, kognitif dan bahasa (Sit, M, dkk, 2016: 57).

Di sekolah taman kanak-kanak bahkan kelompok bermain dianjurkan untuk menyediakan kelas atau tempat untuk sentra peran dan bahasa sebagai upaya untuk mengoptimalkan kecerdasan bahasa anak. di sentra ini diharapkan anak akan dapat mengeksplorasi tentang peristiwa-peristiwa dan ekspresi bagaimana yang sebaiknya mereka tunjukkan serta peran apa yang seharusnya diambil pada saat peristiwa tersebut berlangsung. Anak-anak dapat bebas berkreativitas untuk mengekspresikan imajinasi mereka saat berperan sebagai bapak, ibu, kakak, adik dan anggota keluarga lainnya. Pada saat bermain peran, guru dapat mengetahui jalinan hubungan yang terjadi pada anak saat di rumah, sekolah dan lingkungan masyarakat. Selain itu anak juga dapat mengekspresikan dirinya sesuai profesi yang sedang diperankan seperti guru, dokter, pedagang, TNI/ Polri dan profesi lainnya.

Hal diatas selaras dengan pernyataan Suyanto (2005: 186) bahwa melatih anak belajar bahasa dilakukan dengan cara berkomunikasi melalui berbagai setting yang salah satunya adalah bermain peran (role playing), seperti memerankan penjual dan pembeli, guru dan murid, orangtua dan anak dan sebagainya.

Selain anak bermain peran dengan melibatkan diri dan tubuhnya sebagai anggota keluarga atau memainkan berbagai profesi atau bermain peran makro. Anak juga dapat bersikap sebagai dalang atau sutradara dengan menggunakan berbagai media dalam bermain peran, seperti boneka, wayang, berbagai miniatur (rumah, mobil-mobilan, alat masak, dan sebagainya) atau disebut dengan bermain peran mikro. Pada saat anak bermain peran mikro anak juga dapat mengekspresikan diri dan menyampaikan pikiran dan perasaannya dengan menggunakan media tersebut. Hal ini sependapat dengan pernyataan Susanti, Y. O (2017: 67) bahwa bermain peran mikro dapat meningkatkan kemampuan berbicara anak. Ketika anak bermain peran pada saat itu anak akan menyampaikan atau mengucapkan yang ada dalam pikirannya.

Pemahaman tentang perkembangan bahasa, bukan saja dalam bentuk bahasa secara lisan, namun mencakup empat keterampilan berbahasanya. Empat keterampilan berbahasa yang dimaksud meliputi menyimak (mendengarkan), berbicara, membaca, dan menulis (menggambar). Empat keterampilan berbahasa ini dapat difasilitasi dengan berbagai kegiatan pada PAUD (Anita, 2015: 163). 
Tahapan pelaksanaan dramatic play (bermain peran) adalah sebagai berikut (Zahro, I. F, 2018):

1. Mengidentifikasi tokoh dalam bermain drama/ peran yang akan dimainkan. Mengidentifikasi tokoh yang merepresentasikan anak dan tokoh-tokoh lainnya yang menunjukkan orang-orang yang memiliki peran penting dalam kehidupan anak (Erford, B. T, 2016: 83). Anak dapat memilih sendiri tokoh yang diinginkannya. Anak dapat menceritakan apapun yang dipikirkan dan dirasakannya atas tokoh yang diperankannya. Atau pendidik dapat mengarahkan karakter tokoh yang akan dimainkan anak, selanjutnya anak memainkan tokoh sesuai jenis tokoh dan karakter yang telah ditentukan;

2. Menentukan setting cerita, alternatif peran dan property yang dibutuhkan. Setting cerita meliputi lokasi, waktu, perasaan tokoh, permasalahan atau cerita yang akan dilakonkan. Konselor menawarkan alternatif peran yang akan diperankan saat mendampingi anak yakni drama paralel, co-drama atau tutorial drama. Konselor dalam hal ini orangtua, guru atau tenam bermain peran sesuai dengan kebutuhan anak dan memfasillitasi agar permasalahan konseli dapat teratasi

3. Menginterpretasikan cerita atau nilai-nilai yang terkandung dalam cerita kepada anak. Pada tahap ini, anak dan pendidik menggambarkan cerita dan nilai-nilai apa saja yang terkandung dalam cerita tersebut dan hal-hal yang terkait dengan kondisi anak (Erford, B. T, 2016: 84)

4. Merefleksikan cerita kepada anak. Pada proses ini, anak diajak berdiskusi tentang cerita. Mengajak anak mendiskusikan permasalahan dan cerita akan meningkatkan kemampuan akalnya. Sebagaimana yang dilakukan Umar bin Khathab yang berdialog dengan anakanak, hingga pada permasalahan yang penting beliau meminta pendapat mereka (AthThanthawi dalam Suwaid, M. N. A. H, 2010: 181).

5. Mengobservasi reaksi anak. Amati reaksi-reaksi anak selama diberikan refleksi.

\section{Penutup}

Stimulasi terhadap perkembangan bahasa anak perlu dilakukan oleh orangtua dan pendidik. Perkembangan bahasa yang sesuai dengan tahapan perkembangan akan bermanfaat bagi anak dalam bersosialisasi dengan keluarga, teman/ guru di sekolah dan masyarakat sekitarnya. Bahasa yang berkembang dengan baik juga akan berpengaruh pada kemandirian anak. Anak akan melakukan aktivitas untuk memenuji keinginan dan kebutuhannya dengan 
melakukan komunikasi secara verbal dan non verbal. Komunikasi secara verbal adalah upaya anak untuk menyampaikan pikiran dan perasaannya.

Adapun metode yang dapat dilakukan untuk menstimulasi dan mengoptimalkan kecerdasan bahasa anak, diantaranya metode tanya jawab, bercerita, kunjungan wisata dan bermain peran (dramatic play). Metode bermain peran terdiri dari bermain peran makro dan mikro

Berdasarkan kajian dan pembahasan dapat disampaikan bahwa metode bermain drama (dramatic play)/ bermain peran dilakukan dalam beberapa tahapan, yakni mengidentifikasi tokoh, menentukan setting cerita, menginterpretasikan cerita dan nilai yang terkandung, refleksi dan observasi. Penerapan teknik ini diharapkan dapat memberikan optimalisasi kecerdasan bahasa anak usia dini.

\section{Daftar Pustaka}

Anita. "Perkembangan Bahasa Anak Usia Dini”. (Jurnal al-Shifa, Vol. 06. No. 02). 161-180. JuliDesember 2015

Chatib, M. Gurunya Manusia: Menjadikan Semua Anak Istimewa dan Semua Anak Juara. (Bandung: PT Mizan Pustaka, 2011)

Choiriyah S, dkk. "Upaya Meningkatkan Kemampuan Berkomunikasi Lisan Melalui Metode Bermain Peran pada Anak Kelompok B TKIT Nur Hidayah Surakarta Tahun Ajaran 2013/2014”

Djamarah, S. Guru dan Anak Didik: dalam Interaksi Edukatif. (Jakarta: PT Rineka Cipta, 2005)

Erford, Bradley T. 40 Teknik yang Harus Diketahui Setiap Konselor, Helly Prajitno Soetjipto, dkk (Yogyakarta: Pustaka Pelajar, 2016)

Gunawan, A. W. Genius Learning Strategy. (Jakarta: PT Gramedia Pustaka Utama, 2012)

Hurlock, E. B, Psikologi Perkembangan: Suatu Pendekatan Sepanjang Rentang Kehidupan, terj. Istiwidayanti, dkk (Jakarta: Erlangga, 2004)

Jannati, S. R. Metode Bermain Peran Berpengaruh terhadap Kecerdasan Linguistik Anak. (2016)

Massardi, S \& Yudhistira. Pendidikan Karakter dengan Metode Sentra. (Jakarta: Esmass, 2012) 
Musfiroh, T. Bercerita untuk Anak Usia Dini. (Jakarta: Pendidikan Nasional Direktorat Jenderal Pendidikan Tinggi Direktorat Pembinaan Pendidikan dan Ketenagakerjaan Perguruan Tinggi, 2005)

Musfiroh, T. Stimulasi Kecerdasan Motorik dan Bahasa untuk Anak Usia TPA dan Kelompok Bermain. (2005)

Nuraini, dkk. Bermain Kreatif Berbasis Kecerdasan Jamak. (Jakarta: Indeks, 2010)

Sit, M, dkk. Pengembangan Kreativitas Anak Usia Dini: Teori dan Praktek. (Medan: Perdana Publishing, 2016)

Susanti, Y. O. "Meningkatkan Kemampuan Berbicara Anak melalui Bermain Peran Mikro". (Jurnal Potensia, Vol. 2. No. 1), 63-70. 2017

Suwaid, M. N. A. H. Prophetic Parenting: Cara Nabi SAW Mendidik Anak, Farid Abdul Aziz Qurusy (Yogyakarta: Pro U-Media, 2010)

Suyanto, S. Dasar-dasar Pendidikan Anak Usia Dini. (Yogyakarta: Hikayat Publishing, 2005)

Utami, H. D. Penerapan Bermain Peran dalam Meningkatkan Kecerdasan Berbahasa pada Anak Kelompok B TKIT Insan Harapan Ngawen Klaten Tahun Ajaran 2013/ 2014. (2014)

Tedjasaputra, M. Bermain, Main dan Permainan. (Bandung: Remaja Rosdakarya, 2003)

Yamin, M. Strategi Pembelajaran Berbasis Kompetensi. (Jakarta: Gaung Persada, 2009)

Zahro, I. F. "Optimalisasi Perilaku Prososial Anak Prasekolah melalui Dramatic Play". (Journal of Education and Counseling, Volume 1, No 1), Juni 2018 